\title{
Optimal flow for brown trout: Habitat - prey optimization
}

\author{
Riccardo Fornaroli *, Riccardo Cabrini, Laura Sartori, Francesca Marazzi, Sergio Canobbio, Valeria Mezzanotte \\ Department of Earth and Environmental Sciences, University of Milano-Bicocca, Milano, Italy
}

\section{H I G H L I G H T S}

- The correct definition of environmental flows is essential to guide policy.

- We define optimal flows using both physical habitat and prey availability.

- Most of the habitat for juvenile and fry brown trout is available at low flows.

- Total biomass of prey always increased with increasing flows.

- The effects of flows on macroinvertebrate population cannot be neglected.

\section{A R T I C L E I N F O}

\section{Article history:}

Received 25 February 2016

Received in revised form 8 June 2016

Accepted 8 June 2016

Available online 16 June 2016

Editor: D. Barcelo

\section{Keywords:}

Prey availability

Physical habitat modeling

Quantile regression

Suitability curve

Fish

Invertebrates

Mesohabitat

\section{G R A P H I C A L A B S T R A C T}

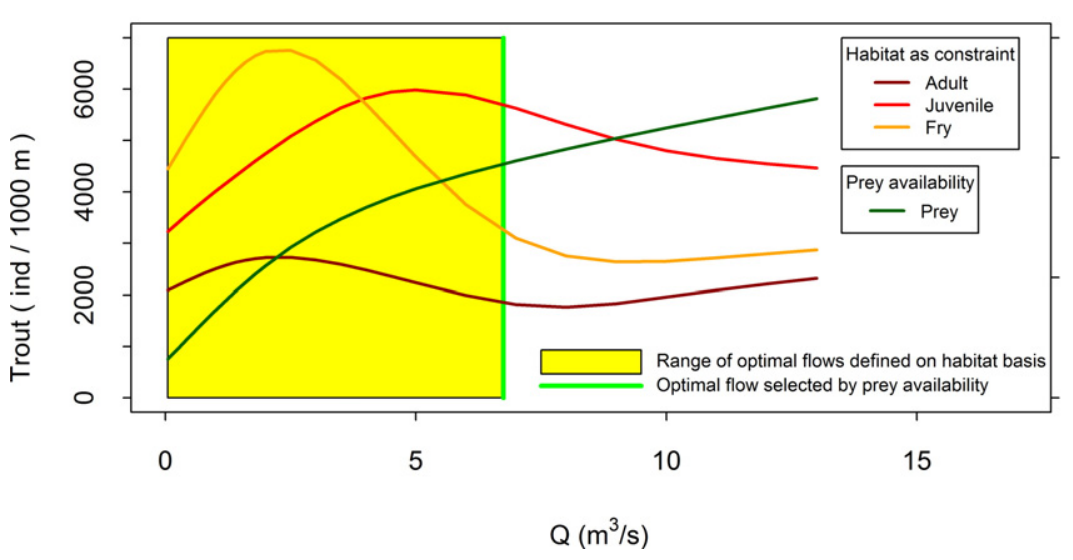

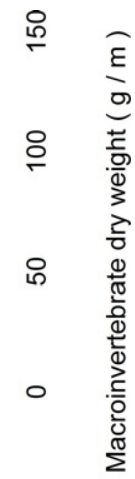

\begin{abstract}
The correct definition of ecosystem needs is essential in order to guide policy and management strategies to optimize the increasing use of freshwater by human activities. Commonly, the assessment of the optimal or minimum flow rates needed to preserve ecosystem functionality has been done by habitat-based models that define a relationship between in-stream flow and habitat availability for various species of fish.

We propose a new approach for the identification of optimal flows using the limiting factor approach and the evaluation of basic ecological relationships, considering the appropriate spatial scale for different organisms. We developed density-environment relationships for three different life stages of brown trout that show the limiting effects of hydromorphological variables at habitat scale. In our analyses, we found that the factors limiting the densities of trout were water velocity, substrate characteristics and refugia availability. For all the life stages, the selected models considered simultaneously two variables and implied that higher velocities provided a less suitable habitat, regardless of other physical characteristics and with different patterns. We used these relationships within habitat based models in order to select a range of flows that preserve most of the physical habitat for all the life stages. We also estimated the effect of varying discharge flows on macroinvertebrate biomass and used the obtained results to identify an optimal flow maximizing habitat and prey availability.
\end{abstract}

(C) 2016 Elsevier B.V. All rights reserved.

\footnotetext{
* Corresponding author.

E-mail address: riccardofornaroli@gmail.com (R. Fornaroli).
}

\section{Introduction}

Freshwater is a fundamental and limiting resource, both for the development of human society and for the maintenance of biodiversity 
and functionality of aquatic ecosystems. Human demand for water is constantly increasing, chiefly for hydroelectric power production and for agricultural purposes (de Fraiture and Wichelns, 2010). The production of hydroelectric power is a great opportunity to reduce our dependence on fossil fuels and the emissions of greenhouse gases. However, hydroelectric power plants necessarily modify the riverine ecosystems.

Scientists are challenged to define ecosystem needs clearly enough to guide policy and management strategies in order to optimize the use of water (Poff et al., 2003). In fact, the conservation of high biodiversity and ecosystem functionality depends on the release of adequate stream flows.

Habitat-based models have been widely used to define a relationship between in-stream flow and habitat availability for various species of fish and, thus, to define the optimal or minimum flow rate (i.a. Gore et al. 1991, Maddock 1999, Ayllón et al. 2010).

These kinds of models basically include hydraulic simulation and suitability curves for target species and thus define a relationship between the flow and the availability of habitat for aquatic organisms. The conceptual basis of habitat based models is ecological.

It is well known that fish and macroinvertebrates do not occupy any environment regardless of hydraulics inside the river, but they show strong preferences for certain values of the hydromorphological parameters such as water depth, current velocity, substrate size and composition (Dolédec et al., 2007; Van Liefferinge et al., 2005). When the flow rate varies, also the depth, the current velocity and often the type of substrate that is gained/lost from the river change and, consequently, the habitat availability for the reference species in the considered stretch of river changes too. Moreover, generally the relationship among physical habitat and aquatic organism densities consider the availability of suitable physical habitat as the only limiting factor. This assumption is not always true. Production may also be limited by water quality (Kail et al., 2012; Morrissey et al., 2013), by the activities of man (Fjeldstad et al., 2012; Hansen and Hayes, 2012), or by events and conditions occurring at a temporal and spatial scale beyond the scope of the model application (Bonada et al., 2008; Comte et al., 2013; Menge et al., 2011). So, some critiques to the habitat-based approach have already been done: i) habitat based models generally do not take into account the effects of flow management on macroinvertebrate populations that in many cases represent the main food source for fish (Eros et al., 2012; Lagarrigue et al., 2002; Rosenfeld and Ptolemy, 2012; Sánchez-Hernández and Cobo, 2012), ii) the suitability curves normally deliver information about where an individual fish is likely to position itself in the river at the microhabitat scale while for the management of ecological flow mesohabitat distribution is important too. Using this information to understand the consequences at management scale (e.g., on a stretch of river) can also be questionable (Parasiewicz and Walker, 2007).

In all cases, physical habitat is a necessary, but not sufficient condition for the production and survival of aquatic organisms. Thus, the results of habitat based models may best be viewed as indicators of population potential in systems where the habitat conditions described by the model are major population constraints. In this perspective, the use of density-environment relationships that show the limiting effects of the habitat characteristics and not the average effects of the same variables seems more adequate.

In field studies, a variety of factors such as competition for space and predation (Ayllón et al., 2013; Kaspersson et al., 2013), temperature (Lecomte and Laplanche, 2012; Moore et al., 2012), climate change (Comte et al., 2013), presence of waterfalls or dams and flow variability (Fjeldstad et al., 2012), changes in habitat structures (Muotka and Syrjänen, 2007) and stochasticity are shown to affect the abundance and the distribution of fish. Each of these factors can influence the relationship among the density of organisms and the habitat characteristics, inflating variability.

Thus, it is often very difficult to disentangle the different sources of variation in the organism density and abundance along gradients using methods based on models testing hypotheses about central tendency of response (e.g. ANOVA, ordinary least square regression) that set aside the concurring role of other unmeasured factors (Austin, 2007).

From the ecological point of view, testing hypotheses about the environmental gradients as limiting factors or constraints on the density of organisms could be more informative than testing them about "average" responses (Downes, 2010). Limiting factors typically result in wedge-shaped relationships with small changes in the mean value of the response variable along the gradient of the independent variable, but with large changes at the upper end of the distribution (Kail et al., 2012; Lancaster and Belyea, 2006).

Quantile regression allows the association of the different rates of change (slopes) to the different parts of the response distribution, being a method for estimating relationships among variables for all the portions of a probability distribution (Koenker and Bassett, 1978). This statistical tool was introduced in ecology by Cade et al. (1999) and can be used to test the role of environmental factors as constraints. Moreover, its application allows the predictions not only of the more probable values of the studied biological metric but also of the maximum or minimum values that could be expected in environmental conditions comparable to the ones used for the model fitting (Cade and Noon, 2003; Doll, 2011; Fornaroli et al., 2015).

In the Alpine streams and rivers brown trout (Salmo trutta) is commonly considered as the target species for this kind of evaluation. The relationships among the density of brown trout and environmental variables have been deeply studied in freshwater ecosystems (Armstrong et al., 2003; Ayllón et al., 2009; Vismara et al., 2001; Winkle et al., 1998). Macroinvertebrates are rarely used in habitat-based methods because of the high heterogeneity of the density response along environmental gradients. However, density-environment relationships for macroinvertebrates were produced on the basis of the limiting factor approach (Fornaroli et al., 2015) and can be used, along with the one produced in this work for fish, to better understand the possible changes induced in the biological communities by water management strategies.

In this work we propose a new concept for the identification of optimal flows using the limiting factor approach, the evaluation of basic ecological relationships and the use of the appropriate spatial scale for the different organisms.

\section{Materials and methods}

\subsection{Study area}

The study area is the Alpine Valley of the Serio River in northern Italy. It was chosen because it provides a large variety of environmental conditions. The river substratum varies from sand to bedrock including all the intermediate substrate classes with a heterogeneous distribution. Despite the presence of dams, this stretch of the river can be considered to be near-pristine due to the absence of other anthropogenic impacts (Canobbio et al., 2010). The basin area of the sampling sites ranges from 90 to $268 \mathrm{~km}^{2}$, the slope from 1.1 to $2.7 \%$, the elevation from 486 to 773 m.a.s.l. and the Strahler river order number from 2 to 3.

\subsection{Fish sampling}

In order to produce habitat suitability curves, fish sampling was performed according to Mäki-Petäys et al. (1997) and Van Liefferinge et al. (2005). Electrofishing was conducted (always by the same team) in 13 sites by wading along a section of the river using a generator-powered unit (Honda ELT60 II GI), with a fixed cathode and a $2.5 \mathrm{~m}$ anode pole (32 cm diameter anode ring). To minimize the flight bias, which may cause the displacement of individuals from their original position, a modified point electrofishing procedure was used. The activated anode was submerged for several seconds every 0.5-1.0 m (measured between the anode centers of two consecutive 'dippings'). 
The point of the first sighting of fish was noted with a different reconnaissance symbol (colored stake) in order to know the placement of the different individuals after electrofishing. To avoid faulty observations of habitat utilization caused by the displacement of individuals due to flight from the electric current, each study section was sampled only once with this technique.

Captured trout were measured and assigned to one of three size classes $<10,10-15,>15 \mathrm{~cm}$, roughly corresponding to fish ages of $0+$ (fry), $1+$ (juvenile), and $2+$ (adult) respectively (Mäki-Petäys et al., 1997) before being returned unharmed to the water. Some individuals were also stomach-flushed (Bridcut and Giller, 1995), and the ingested prey were collected and identified in laboratory.

\subsection{Characterization of sampling sites, habitat use and availability}

After sampling, different habitat descriptors were measured for each individual in order to define the habitat use. We measured water velocity and water depth using a Marsh-McBirney Flo-Mate Model 2000 portable flowmeter. Water velocity was measured at $40 \%$ of the depth in order to obtain the mean velocity of the water column in the sampling point.

The substrates were classified as dominant, sub-dominant and matrix as the more abundant, the second more abundant or the finer class which occupies the interstices between the larger sized elements. We expressed their relative abundance in percentage according to the mineral substrate classes provided by the site description protocol in the AQEM Manual (AQEM Consortium, 2002) modified in order to better describe also the fish habitat as follows:

- gigalithal $>1 \mathrm{~m}$ (blocks and bedrock)

- megalithal $>0.4 \mathrm{~m}$ to $1 \mathrm{~m}$ (large cobbles and boulders)

- macrolithal $>0.2 \mathrm{~m}$ to $0.4 \mathrm{~m}$ (head-sized cobbles)

- mesolithal $>0.06 \mathrm{~m}$ to $0.2 \mathrm{~m}$ (fist to hand-sized cobbles)

- microlithal $>0.02 \mathrm{~m}$ to $0.06 \mathrm{~m}$ (coarse gravel with variable percentages of medium gravel)

- akal $>0.002 \mathrm{~m}$ to $0.02 \mathrm{~m}$ (fine to medium-sized gravel)

- sand and mud $<0.002 \mathrm{~m}$.

Using these three descriptors we derived the maximum substrate size (MSS) and the percentage of fine substrates. MSS was represented by the bigger class diameter among the dominant and sub-dominant substrates. The percent of the fine fraction was obtained summing the relative percentage of substrate classes with size below $0.06 \mathrm{~m}$.

The availability of refugia was also evaluated. Refugia can be vegetation (aquatic or overhanging), wood debris, undercut banks and many others (Allouche, 2002) but in the studied sites the discontinuities in the riverbed profile where the depth of water was higher than $0.30 \mathrm{~m}$ and the MSS was $>0.5 \mathrm{~m}$ (boulders and blocks) were the only available refugia.

After fish community assessment, the sampling sites were further characterized extending the measurement of depth and velocity and the evaluation of substrates and refugia availability to multiple spatial referenced points (from 20 to 40 point per each site) chosen in order to represent the within site variability.

Starting from these series of discrete points of measurement, a $1 \mathrm{~m}^{2}$ cell map of the distribution for each variable was created using GRASS GIS (GRASS Development Team, 2012) and the inverse distance squared weighting algorithm using the command $v$.surf.idw. This algorithm fills a raster matrix with interpolated values generated from a set of irregularly spaced vector data points using numerical approximation techniques. The interpolated value of a cell is determined by values of the 12 nearest data points and the distance of the cell from those input points. In comparison with other methods, numerical approximation allows representation of more complex surfaces, particularly those with anomalous features such as water velocity or substrate diameter.

Using the maps of water velocity and depth for each site and considering the river segment features a reclassified habitat map was produced following these criteria: i) if depth was lower than $0.5 \mathrm{~m}$ and water velocity slower than $0.3 \mathrm{~m} / \mathrm{s}$ the assigned mesohabitat was shallow pool; ii) if depth was higher than $0.5 \mathrm{~m}$ and water velocity slower than $0.3 \mathrm{~m} / \mathrm{s}$ the assigned mesohabitat was deep pool; iii) if depth was lower than $0.5 \mathrm{~m}$ and water velocity higher than $0.3 \mathrm{~m} / \mathrm{s}$ the assigned mesohabitat was riffle; iv) if depth was higher than $0.5 \mathrm{~m}$ and water velocity higher than $0.3 \mathrm{~m} / \mathrm{s}$ the assigned mesohabitat was run. These maps were compared with the visual surveys made in the field and the identification of the different habitats was very similar between the two methods. As an example, Fig. 1 shows all the maps produced for one of the sampling sites.

For each habitat in the reclassified map the mean water velocity, depth, fine percentage and MSS were evaluated averaging the values of each cell. Differently, the availability of refugia was calculated by dividing the number of cells classified as refugia for the number of total cells.
A

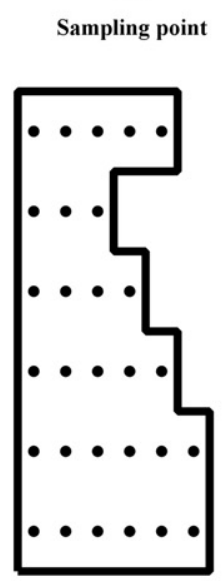

B

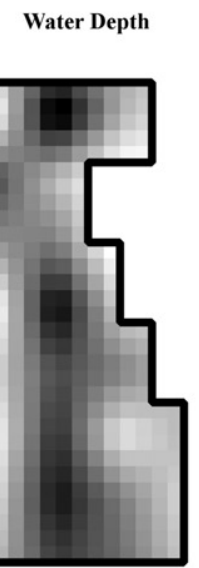

0.01
C

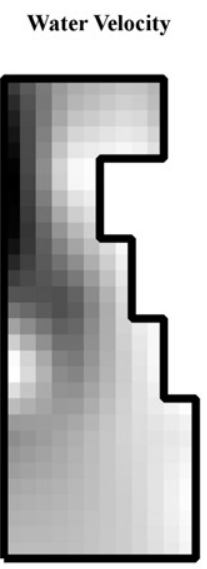

0.00
D

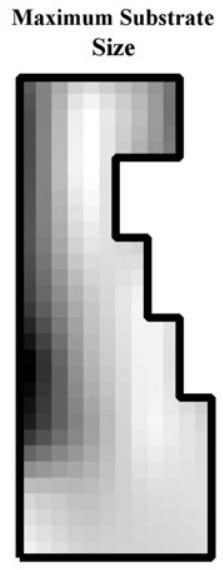

0.01
E
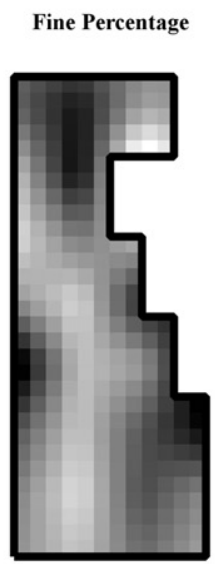

0.00

0.94

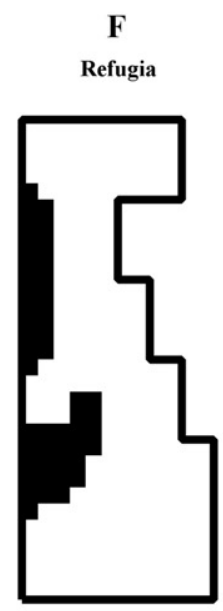

G

Habitat Classification

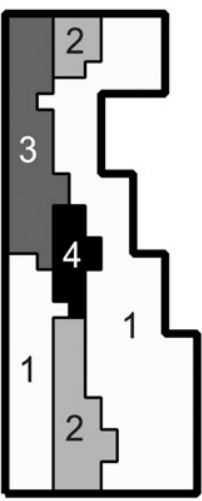

m

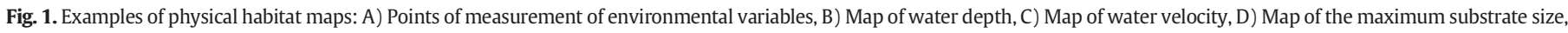

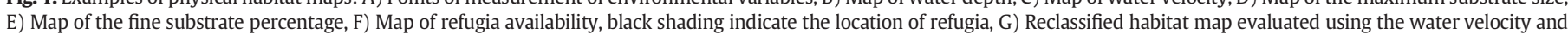
water depth maps, number 1 indicate shallow pools, number 2 indicate deep pools, number 3 indicate riffles and number 4 indicate runs. 
Table 1

Model equations used to describe the effect of a single gradient.

\begin{tabular}{ll}
\hline Model & Equation \\
\hline Linear & $y=\mathrm{a}+\mathrm{b} * x$ \\
Logarithmic & $y=\mathrm{a}+\mathrm{b} * \log _{10}(x)$ \\
Exponential & $y=\mathrm{a}+\mathrm{b} * \mathrm{e}^{(x)}$ \\
Quadratic & $y=\mathrm{a}+\mathrm{b} * x+\mathrm{b} * x^{2}$ \\
\hline
\end{tabular}

Each captured fish was then assigned to a specific habitat on the basis of the characteristics noted during the electrofishing and the real position in the sampling site. The abundance of each age class in each habitat was calculated by summing the number of fish captured and dividing the total by the class area.

\section{Calculations}

\subsection{Development of quantitative habitat suitability models}

To avoid multicollinearity a selection of variables using Variance Inflation Factor (VIF) were performed before quantile regression analyses (Neter et al., 2004). The variables were maintained if the VIF values were below 5 . Since the wide range of values of raw data all the independent variables were unit-based standardized $\left[\mathrm{X}^{\prime}=\left(\mathrm{X}-\mathrm{X}_{\mathrm{min}}\right) /\right.$ $\left(\mathrm{X}_{\max }-\mathrm{X}_{\min }\right)$ ].

The relationships among the dependent and the independent variables were studied at different quantiles $(0.50,0.75,0.80,0.85,0.90)$. Usually, hypotheses about the central response of organisms to environmental gradients are tested, although the effects of other variables may influence such response and decrease the fit of the model, which may even become uninformative (Lancaster and Belyea, 2006). In this perspective, quantile regression, calculated at the extreme quantiles, allows the chosen independent variables to be considered as "constraints" to the distribution of biological communities, without compromising the model causal relationship (Cade et al., 1999). Regressions of the extreme quantiles characterize the slope and shape of the boundaries of the data, when biological metrics are tested against environmental gradients (e.g., habitat availability). Hence, quantile regression has been used instead of traditional central response models in order to examine with more ease the boundaries of density-habitat relationships, i.e. the upper limits imposed by the limiting factors. We fitted linear, exponential, logarithmic and quadratic curves to the data. We also created a mesohabitat-level dummy variable for evaluate fixed-effects for different intercepts among habitat categories. Thus, three categorical variables (Deep pool, Riffle, Run) for the four habitat categories were included in our models in order to account for their effects on intercept. In summary, we generated 8 univariate models for each pair of the dependent and independent variables, evaluating 4 model forms and considering as present or absent, for each of them, the fixed effect among mesohabitats. The mathematical equations for the model forms are reported in Table 1.
Later we used the best-fitting univariate models (as a general rule of thumb, the models with $w_{i}>10 \%$ of the highest one) to fit multivariate quantile regression models combining the selected variables, considering both the presence and absence of different intercepts for mesohabitats.

The statistical analyses were conducted using the quantreg (Koenker, 2015) package in R Project software (R Core Team, 2015). For each model a $\tau$-specific version of Akaike Information Criterion, corrected for small sample size ( $\mathrm{AICc}(\tau))$, was calculated for every studied quantile. The difference between the model $\operatorname{AIC} c(\tau)$ and the minimum AICc $(\tau)$ could be used in order to choose the best-fitting model $(\Delta \mathrm{i}=\operatorname{AICc}(\tau)-\min \operatorname{AICc}(\tau))$, considering that the model with the lowest $\operatorname{AICc}(\tau)$ generally provides the best description of the data. Values of $\Delta \mathrm{i} \geq 2$ are suggested as a threshold to exclude alternative models; values of $\Delta \mathrm{i}<2$ indicate substantial support for the alternative model (Burnham and Anderson, 2002; Johnson and Omland, 2004). For each model, we reported the Akaike weights $\left(w_{i}\right)$, representing the relative likelihood of a model, given a data set and a set of models (Burnham and Anderson, 2002). We determined the best models across the studied quantiles by averaging $w_{i}$ for each model from all five quantile model selection analyses (Allen and Vaughn 2010, Fornaroli et al. 2015).

We used the selected models in order to predict the maximum trout densities along the alpine valley of the Serio river. As all the selected models for density were not better than a constant model at the 10th quantile (for each life stage the constant model at the $10^{\text {th }}$ quantile was: $y=0$ ), only the upper boundaries, represented by $90^{\text {th }}$ quantile, were used in order to predict densities. Thus, the $90^{\text {th }}$ quantile regression estimates can be regarded as 1 -side upper $90 \%$ prediction intervals where the lower bound is assumed to be 0 .

As the models were constructed using unit-based standardized variables to address their relative importance, after the selection of the best models we used again raw data to fit the models in order to make predictions using non-standardized variables.

\subsection{Habitat simulations}

We selected 8 sites, different from those used for the suitability evaluation, in order to model the changes induced by flow modifications on physical habitat. The collected data were used as input to simulate the habitat features and availability by PHABSIM (Physical Habitat Simulation Model) (Waddle, 2001) which has been used for decades in ecological flow studies.

We identified 2 or 3 representative cross sections in each site (for a total of 21 representative sections). The sections were placed at a distance comparable to the stream width and in order to represent properly the morphological variability, so the distance between sections was not the same in all sampling sites. We carried out several hydro-morphological surveys in order to characterize the flow. In each section we measured water velocity, depth, substrate size and refugia availability every $0.5-1 \mathrm{~m}$. Water velocity and depth measurements were repeated 3 or 4 times with different flows in order to produce a

Table 2

Mean values and standard deviations of the characteristics of the sampled habitats and mean trout densities. All variables are grouped by habitat type.

\begin{tabular}{|c|c|c|c|c|}
\hline \multirow[b]{2}{*}{ Variable } & \multicolumn{4}{|l|}{ Habitat (n) } \\
\hline & Shallow pools (31) & Deep pools (10) & Riffles (17) & Runs (15) \\
\hline Area $\left(m^{2}\right)$ & $59 \pm 55$ & $84 \pm 83$ & $117 \pm 263$ & $21 \pm 22$ \\
\hline Depth (m) & $0.25 \pm 0.08$ & $0.67 \pm 0.11$ & $0.30 \pm 0.08$ & $0.65 \pm 0.17$ \\
\hline Water velocity (m/s) & $0.138 \pm 0.068$ & $0.129 \pm 0.049$ & $0.442 \pm 0.088$ & $0.465 \pm 0.186$ \\
\hline $\operatorname{MSS}(\mathrm{m})$ & $0.40 \pm 0.25$ & $0.55 \pm 0.18$ & $0.36 \pm 0.23$ & $0.48 \pm 0.20$ \\
\hline Fine percentage (\%) & $34 \pm 18$ & $33 \pm 12$ & $31 \pm 18$ & $24 \pm 14$ \\
\hline Refugia availability (\%) & $25 \pm 34$ & $62 \pm 32$ & $13 \pm 26$ & $35 \pm 44$ \\
\hline Trout (ind $/ \mathrm{m}^{2}$ ) & $0.208 \pm 0.184$ & $0.219 \pm 0.173$ & $0.084 \pm 0.184$ & $0.062 \pm 0.900$ \\
\hline Adult (ind $/ \mathrm{m}^{2}$ ) & $0.047 \pm 0.073$ & $0.156 \pm 0.174$ & $0.006 \pm 0.016$ & $0.017 \pm 0.039$ \\
\hline Juvenile (ind/m²) & $0.078 \pm 0.103$ & $0.040 \pm 0.040$ & $0.060 \pm 0.098$ & $0.014 \pm 0.028$ \\
\hline Fry (ind $/ \mathrm{m}^{2}$ ) & $0.083 \pm 0.097$ & $0.023 \pm 0.300$ & $0.019 \pm 0.042$ & $0.032 \pm 0.072$ \\
\hline
\end{tabular}


Table 3

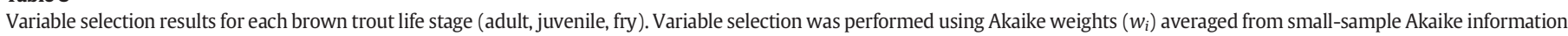

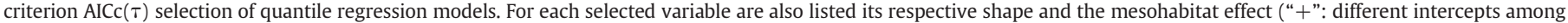
mesohabitat, "-": same intercept for all the mesohabitat). Only the models with the 5 highest average Akaike weights $\left(w_{i}\right)$ are shown.

\begin{tabular}{|c|c|c|c|c|c|c|}
\hline \multirow[t]{2}{*}{ Rank } & \multirow{2}{*}{$\begin{array}{l}\text { Average } \\
w_{i}\end{array}$} & \multicolumn{2}{|c|}{$1^{\text {st }}$ Variable } & \multicolumn{2}{|c|}{$2^{\text {nd }}$ Variable } & \multirow{2}{*}{$\begin{array}{l}\text { Mesohabitat } \\
\text { Effect }\end{array}$} \\
\hline & & Variable & Shape & Variable & Shape & \\
\hline \multicolumn{7}{|c|}{ Adult } \\
\hline 1 & 0.267 & Refugia & Lin & & & + \\
\hline 2 & 0.196 & Refugia & Lin & MSS & Qua & + \\
\hline 3 & 0.086 & Refugia & Lin & Depth & $\log$ & + \\
\hline 4 & 0.082 & Refugia & Lin & Fine $\%$ & Log & + \\
\hline 5 & 0.076 & Refugia & Lin & Velocity & Exp & + \\
\hline \multicolumn{7}{|c|}{ Juvenile } \\
\hline 1 & 0.339 & MSS & Qua & Depth & Qua & + \\
\hline 2 & 0.151 & MSS & Qua & & & + \\
\hline 3 & 0.115 & MSS & Qua & Velocity & Qua & + \\
\hline 4 & 0.098 & MSS & Qua & Refugia & Qua & + \\
\hline 5 & 0.071 & MSS & Qua & Fine $\%$ & Qua & + \\
\hline \multicolumn{7}{|c|}{ Fry } \\
\hline 1 & 0.332 & Fine \% & Exp & Depth & $\log$ & + \\
\hline 2 & 0.149 & Fine $\%$ & Exp & Velocity & Log & + \\
\hline 3 & 0.083 & Fine $\%$ & Exp & & & + \\
\hline 4 & 0.075 & Fine $\%$ & Lin & Depth & Log & - \\
\hline 5 & 0.068 & Fine $\%$ & Lin & Velocity & Qua & - \\
\hline
\end{tabular}

calibration dataset for the PHABSIM habitat modeling. We performed these measurements in situations ranging between low and normal flows. Depending on the sites the flows varied from 0.2 up to $10 \mathrm{~m}^{3} / \mathrm{s}$.

One-dimensional hydraulic models were used to compute depth and velocity in the cross-section. The stage-discharge model (STGQ Waddle 2001) was calibrated using the measured water surface levels recorded during the hydraulic surveys. To calibrate the model, at least three measured water surface levels were used. After calibration, the model simulated the water surface levels at each cross-section for a range of flows from 0.05 to $14 \mathrm{~m}^{3} / \mathrm{s}$, in increments of $0.2 \mathrm{~m}^{3} / \mathrm{s}$ for flows below $2 \mathrm{~m}^{3} / \mathrm{s}$, in increments of $0.5 \mathrm{~m}^{3} / \mathrm{s}$ for flows between $2 \mathrm{~m}^{3} /$ $\mathrm{s}$ and $5 \mathrm{~m}^{3} / \mathrm{s}$ and in increments of $1 \mathrm{~m}^{3} / \mathrm{s}$ for flows over $5 \mathrm{~m}^{3} / \mathrm{s}$. The velocity model (VELSIM) was calibrated with a dataset including at least 3 velocity data using the mean-column velocity measurements. Using this dataset, throughout PHABSIM simulation system we were able to produce maps of water velocity and depth for a wide range of discharge in each site. Then, we imported these microhabitat maps and those produced for MSS, fine substrate percentage and refugia availability in $R$ software for subsequent analysis.

As we have done for the suitability evaluation, and using the same criteria, we used the maps of water velocity and depth for each site at each discharge to produce a reclassified mesohabitat map.

For each habitat in the reclassified map the mean water velocity, depth, fine substrate percentage and the MSS were evaluated averaging the values of each cell. Since in those maps each cell area was different from each other we used the weighted mean based on the cell area in order to evaluate the habitat characteristics. The refugia availability was calculated dividing the area of the cells classified as refugia for the total area of the considered habitat. It is important to note that a cell could be considered as a refuge for some discharge but not for others. As previously mentioned, often refugia are represented by streambed discontinuity but only when the water depth is over $0.3 \mathrm{~m}$. That's why the distribution of refugia is not constant with varying discharge (as the fine percentage and maximum substrate size are) but varies with it.

\subsection{Habitat availability evaluations}

We have defined as microhabitats a portion of the river that has dimensions of one square meter and may represent fairly homogeneous habitat for macroinvertebrates, conversely we defined four kinds of mesohabitats (shallow pool, deep pool, riffle, run) that may represent fairly homogeneous habitat for trout. Once we obtained a comprehensive view of the modifications in the physical habitat, aggregated at these two spatial levels, we proceeded with the evaluation of the suitability for biological populations.

We modeled the potential abundances of six macroinvertebrate families (Leuctridae, Heptageniidae, Baetidae, Limnephilidae, Chironomidae, Limoniidae) using the density models developed in Fornaroli et al. (2015). We evaluated the potential density (ind $/ \mathrm{m}^{2}$ ) in each cell of each site for each discharge and, multiplying this value for the cell area and summing the obtained results, we were able to provide a potential number of individuals in each site for each discharge.

We used the density models developed in this work to evaluate the potential density of each class of age of brown trout in each habitat per site. Then we multiplied the predicted maximum density for the habitat area and we summed the results obtained for all the habitats within a site.

Habitats were classified and described according to the same criteria used during the analyses of field data for the development of density models.

Throughout these procedures we were able to predict the maximum number of organisms (macroinvertebrate and fish) in each site at each discharge.

\subsection{Optimal flow definition}

For each site the considered discharges ranged between $0.050 \mathrm{~m}^{3} / \mathrm{s}$ and the mean annual discharge. The mean annual discharge in each site was calculated using the regionalization procedure developed by Lombardy Region (PTUA, 2006). This procedure, starting from the measured discharge in a downstream section, estimates the mean values of the average annual flow per unit area, scaled according to the average annual rainfall on the respective sub-basins.

The habitat availability - discharge relationships were evaluated by fitting a spline function for each species in each site to the output of the model and using it for making prediction for every $0.050 \mathrm{~m}^{3} / \mathrm{s}$ in the considered range.

For optimal flows definitions in each site we consider only the life stages that show increase in available habitat bigger than $100 \%$ along the flows gradient, values and equation are reported in Table 4. We considered as the most suitable condition for trout development all the discharges that originated a value of habitat availability higher than the median one, for all the considered life stages. In order to select those 
discharges we used, for each life stages, the following equation:

$\mathrm{Q}_{\mathrm{opt}}=$ which $\left.Q \quad \mathrm{HA} \geq \operatorname{median}(\mathrm{HA})\right]$

where $\mathrm{Q}_{\mathrm{opt}}$ are the optimal flows for fish, $\mathrm{Q}$ are vectors of modeled discharge, $\mathrm{HA}$ are vectors of available habitat. Once that we select a range of optimal flows for each life stage we combine the results maintaining only the flows that were selected for all the life stages modeled in that site.

The habitat availability and so the potential abundance of the studied macroinvertebrate families were transformed in the potential dry weight of trout prey using the equations available in Towers et al. (1994), Nyström and Pérez (1998), Stoffels et al. (2003), Canobbio et al. (2008) and summing the results for all the six families.
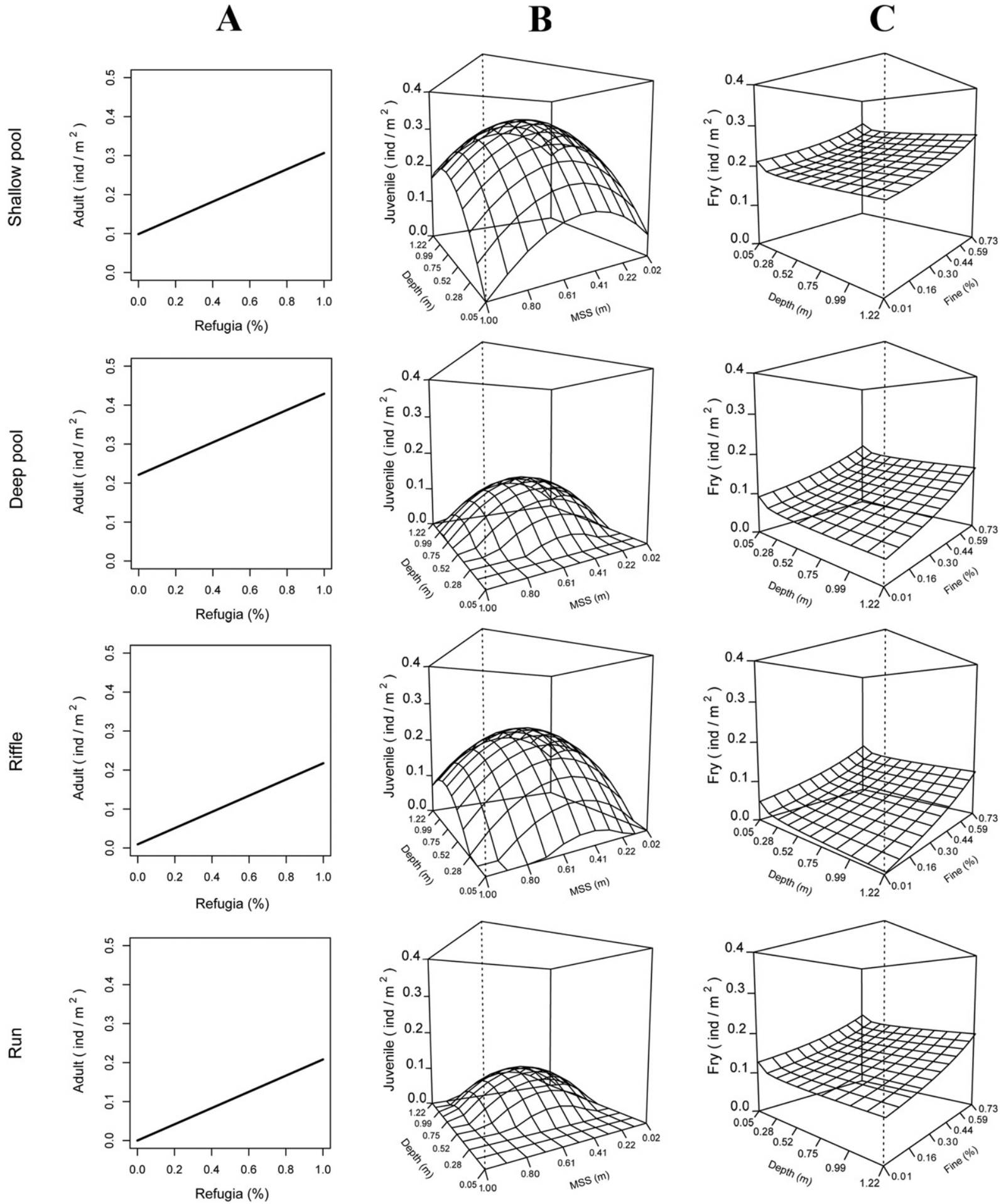

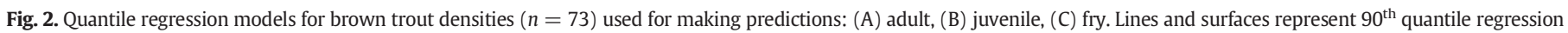
models. 
The acceptable flows are the ones defined as suitable for all the life stages of trout and, inside that range, the flows that maximize the macroinvertebrate (prey) availability are supposed to be better.

\section{Results}

\subsection{Habitat suitability models}

In the 13 sampled sites, a total of 73 different habitat units were characterized. This information is entirely reported in Appendix A and summarized in Table 2.

The measured environmental variables did not show relevant multicollinearity as all the VIF value were below 2 and the value above which multicollinearity is held significant is 10 (O'brien, 2007).

The relationships among the density of the three considered brown trout life stages and the five measured environmental variables were analyzed and the selection results are reported in Table 3, the estimated parameters and confidence intervals for the selected 90th quantile regression models are reported in Appendix B.

Regarding adult brown trout densities, the model considering refugia availability as the independent variable and accounting for mesohabitat effect was selected as the best one (averaged $w_{i}=$ 0.297). The function that best described the effects of refugia was the linear one. Densities of adult brown trout increased with increasing refugia availability (Fig. 2A). At microhabitat scale (small-scale $<1 \mathrm{~m}^{2}$ according to Bult et al., 1999), this could depend on the trend of fish to maximizes their energy gain by maintaining focal positions in low velocities (in this case close to the refugia) adjacent to a high velocity current that supplies drift prey at a relatively high rate, as suggested by Fausch (2014). In this perspective it is clear that refugia availability is a key factor in the studied system. The more suitable mesohabitat for adult brown trout were deep pools followed, in order, by shallow pools, riffles and runs.

In many studies (Muñoz-Mas et al., 2012; Strakosh et al., 2003; Vismara et al., 2001) water depth plays an important role in the definition of habitat suitability for brown trout, our results shows that this effect could be enhanced by the fact that higher depth make new refugia available and also by the fact that deep pool habitat is the preferred mesohabitat.

Conversely, the model considering water depth and MSS as the independent variables and accounting for the mesohabitat effect was selected as the best (averaged $w_{i}=0.339$ ) for describing juvenile brown trout densities. The effect of water depth gradient was best described by the quadratic function with lower values of density for depth lower than $0.3 \mathrm{~m}$ and higher than $1 \mathrm{~m}$. Also the effect of MSS was best described by the quadratic function which predicts higher densities for intermediate size (Fig. 2B). Also in other studies juvenile trout seems to prefer intermediate substrate dimension (Hesthagen and Heggenes, 2003; Louhi et al., 2014; Mäki-Petäys et al., 1997), probably because intermediate gravel provides better cover in the interstitial spaces among particles. At the same time adult fish require larger interstitial spaces and, thus, are more abundant in refugia. The more suitable mesohabitats for juvenile brown trout were shallow pools followed, in order, by runs, deep pools and riffles.

The densities of brown trout fry were more consistently represented by a multivariate model. The model considering water depth and fine substrate percentage simultaneously, and accounting for the mesohabitat effect (averaged $w_{i}=0.332$ ), was selected as the best performing. The functions that best described the effects of fine percentage and water depth were respectively the exponential and the logarithmic one. The higher values of density are predicted for habitat with high percentage of fine substrate and shallow water (Fig. 2C), as
A

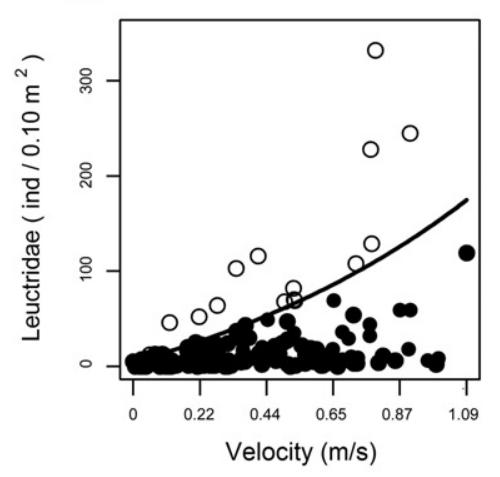

$\mathrm{D}$

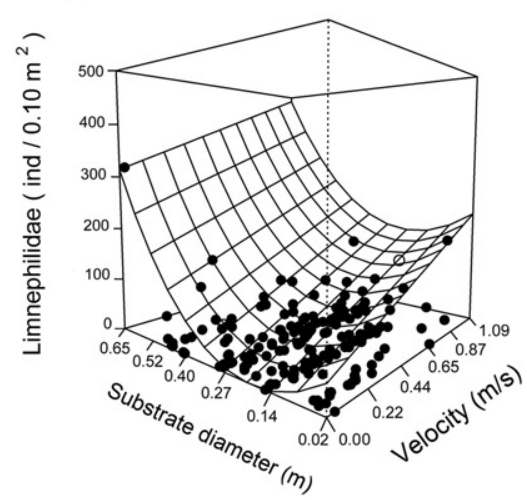

B

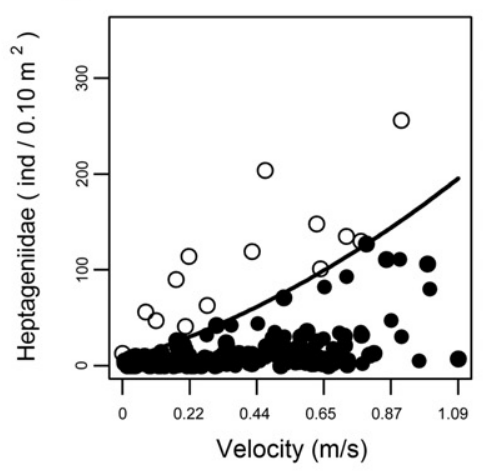

E

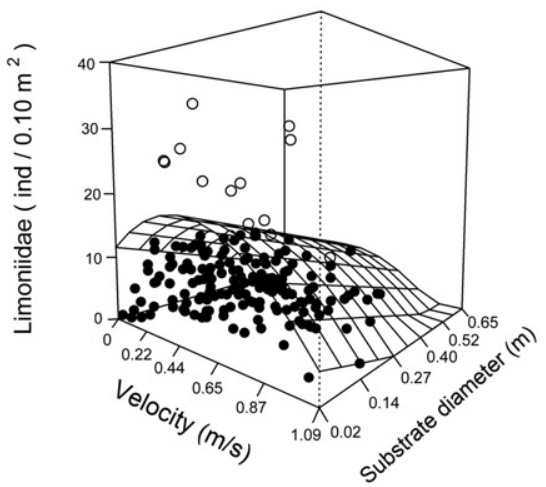

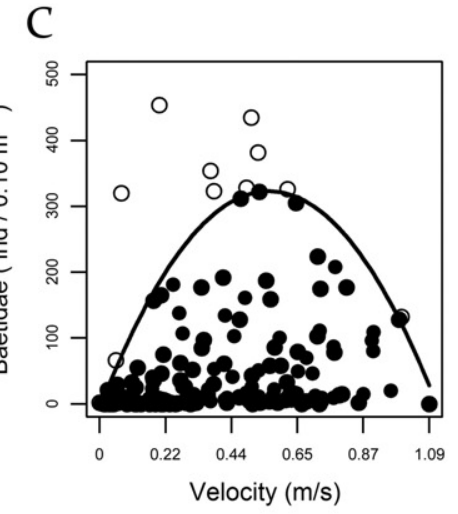

F

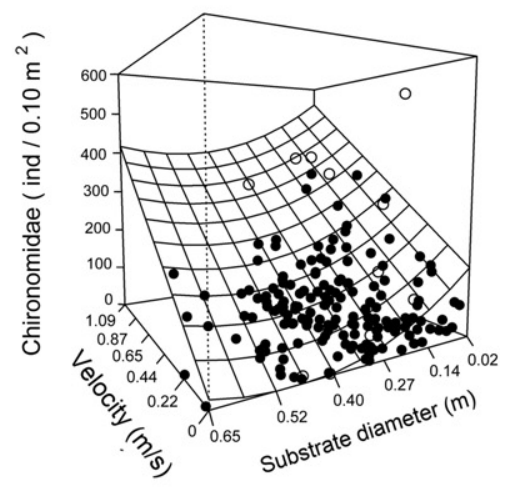

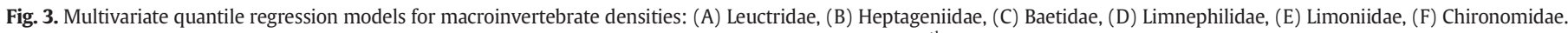

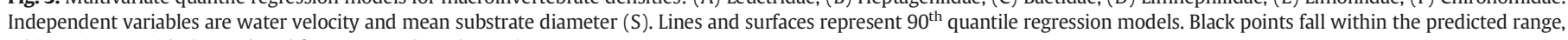
white points outside (reproduced from Fornaroli et al. 2015). 
Table 4

Habitat availability variation for adult, juvenile and fry brown trout in the 8 modeled sites. $X=\left[\left(X_{\max }-X_{\min }\right) / X_{\min }\right] * 100$.

\begin{tabular}{|c|c|c|c|}
\hline \multirow[t]{2}{*}{ Site $^{*}$} & \multicolumn{3}{|c|}{ Habitat availability variation (\%) } \\
\hline & Adult & Juvenile & Fry \\
\hline 1 & $58^{*}$ & $59^{*}$ & 108 \\
\hline 2 & 102 & $75^{*}$ & $64^{*}$ \\
\hline 3 & 251 & $66^{*}$ & 121 \\
\hline 4 & 207 & $34^{*}$ & $58^{*}$ \\
\hline 5 & 200 & 100 & $15^{*}$ \\
\hline 6 & 228 & $35^{*}$ & 336 \\
\hline 7 & $55^{*}$ & $85^{*}$ & 157 \\
\hline 8 & 145 & $18^{*}$ & 124 \\
\hline
\end{tabular}

* Excluded from optimal flow analyses.

also reported by Armstrong et al. (2003). The more suitable mesohabitat for fry brown trout were shallow pools followed, in order, by riffles, deep pools and runs.

Macroinvertebrates are recognized as the main food source for trout in the studied system and in many others (Eros et al., 2012; Sánchez-Hernández and Cobo, 2012). The stomach content analyses revealed that most of the prey ( $87 \%$ ) belongs to larvae of the families: Leuctridae (1\%), Heptageniidae (5\%), Baetidae (44\%), Limnephilidae (31\%), Limoniidae (1\%) and Chironomidae (5\%). Models able to predict the densities of those macroinvertebrate families in the Serio river were produced (Fig. 3) and will be used along those produced for fish in order to define the optimal flows that takes into account the effects of both habitat and prey availability. The models selected to explain the densities of all macroinvertebrate families consider velocity as a main driving force (both in univariate or bivariate models). Macroinvertebrate densities increase with velocity or, in the case of Baetidae and Limoniidae, are greatest for intermediate velocities.

\subsection{Optimal flows}

Habitat availability patterns were generated by the different effects of flow-dependent depth and velocity variations, but also by the substrate characteristics of the gained or lost river bed and later a range of flows that maximize the habitat availability for the different life stages of brown trout were obtained for each modeled site. The area of available habitat in each site, for the different life stages, can increase up to three times (Table 4) in the consider range of flows. Habitats for adult brown trout are the most influenced by flows (Figs. 4 and 5) showing a within-site percentage increase of $156 \pm 77$ (mean \pm sd). Fry brown trout habitats are also related to flows $123 \pm 97$ percentage increase and low flows conditions provide always more suitable habitat than normal flows conditions. Juvenile brown trout habitats are less related to flows $58 \pm 28$ percentage increase and consequently were excluded from the optimal flows calculations for 7 on 8 sites.

The abundance of the macroinvertebrates, and hence their dry biomass, increases monotonically with increasing discharge, in all the studied sites. These results are driven by the suitability models for the macroinvertebrates that predict higher densities in high velocity habitats, such as riffles and run, for almost all the studied families (Fornaroli et al., 2015).

Across the modeled sites, between the minimum and the maximum optimal flows selected for trout, the dry biomass of macroinvertebrate increases by $141 \pm 183 \%$ (Table 5 ). This means that the available energy can increase $>2$ times inside the range of flows that preserve most of the habitat for fish. In order to provide a single value of optimal flow, we selected the ones that maximized the macroinvertebrate biomass that correspond to the right hand hedge of the boxes in Fig. 5 .

\section{Discussion}

Among the modeled sites, higher invertebrate production occurred in mesohabitats with greater water velocities, such as riffles and runs, while fish density increased in pools and near the refugia where the trout could find better cover. In some sites most of the habitats for fish are already available for really low flows, while, on the contrary, the macroinvertebrate biomass always increases with increasing flow, as shown in Fig. 5. Macroinvertebrates are always important as prey for trout and our results highlight and quantitatively describe the different needs of prey and predators.

In our analyses, we found that the factors limiting the densities of trout were water depth, substrate characteristics and refugia availability. For all the life stages, the selected models considered simultaneously more than one variables and implied that the suitability changes among
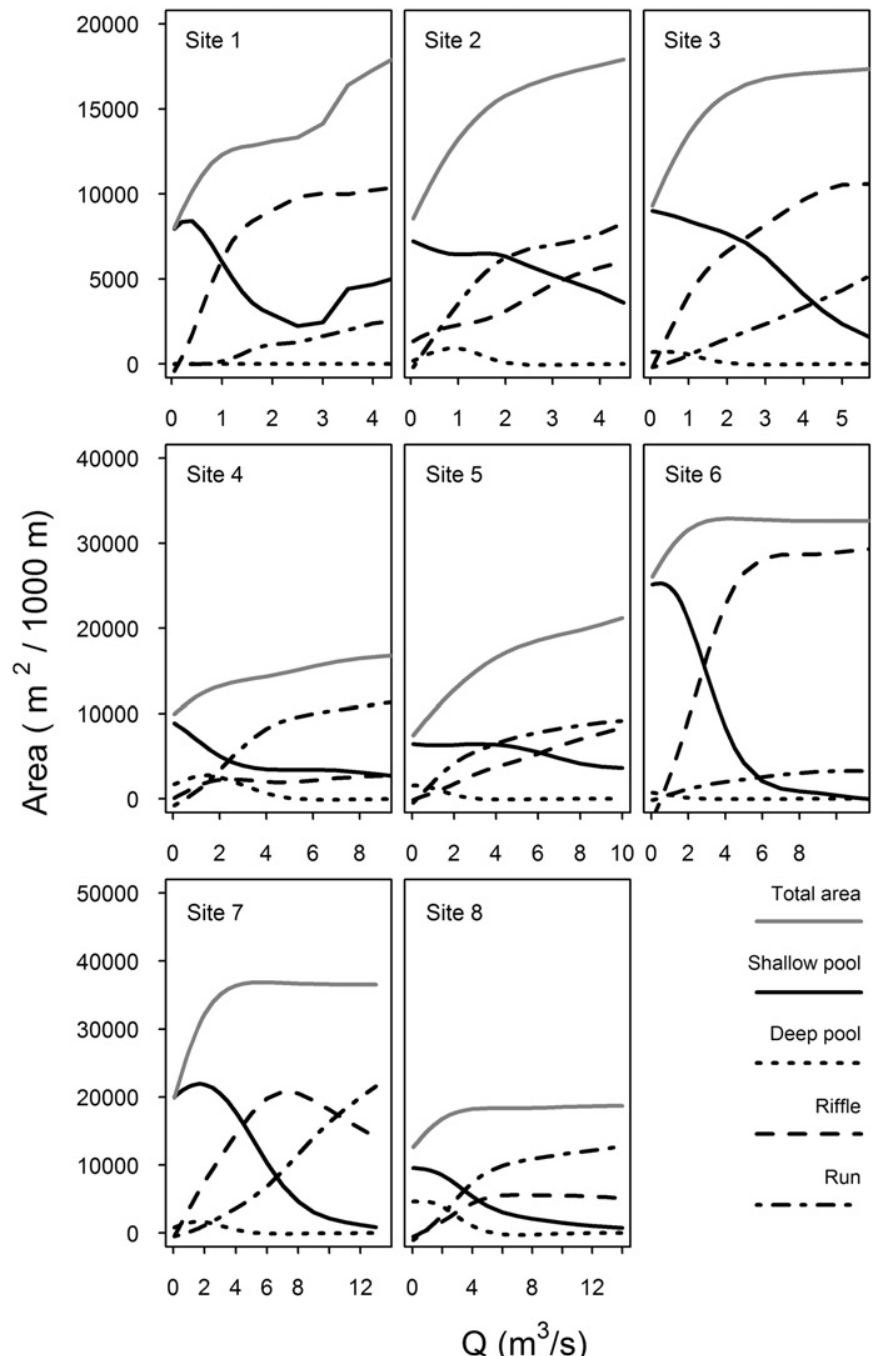

$\begin{array}{lll}4 & 6 & 8\end{array}$

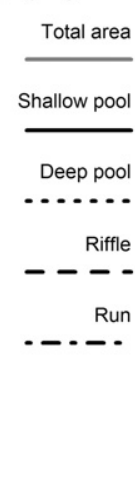

Fig. 4. Trends in mesohabitat availability and total wet area in the 8 modeled sites 

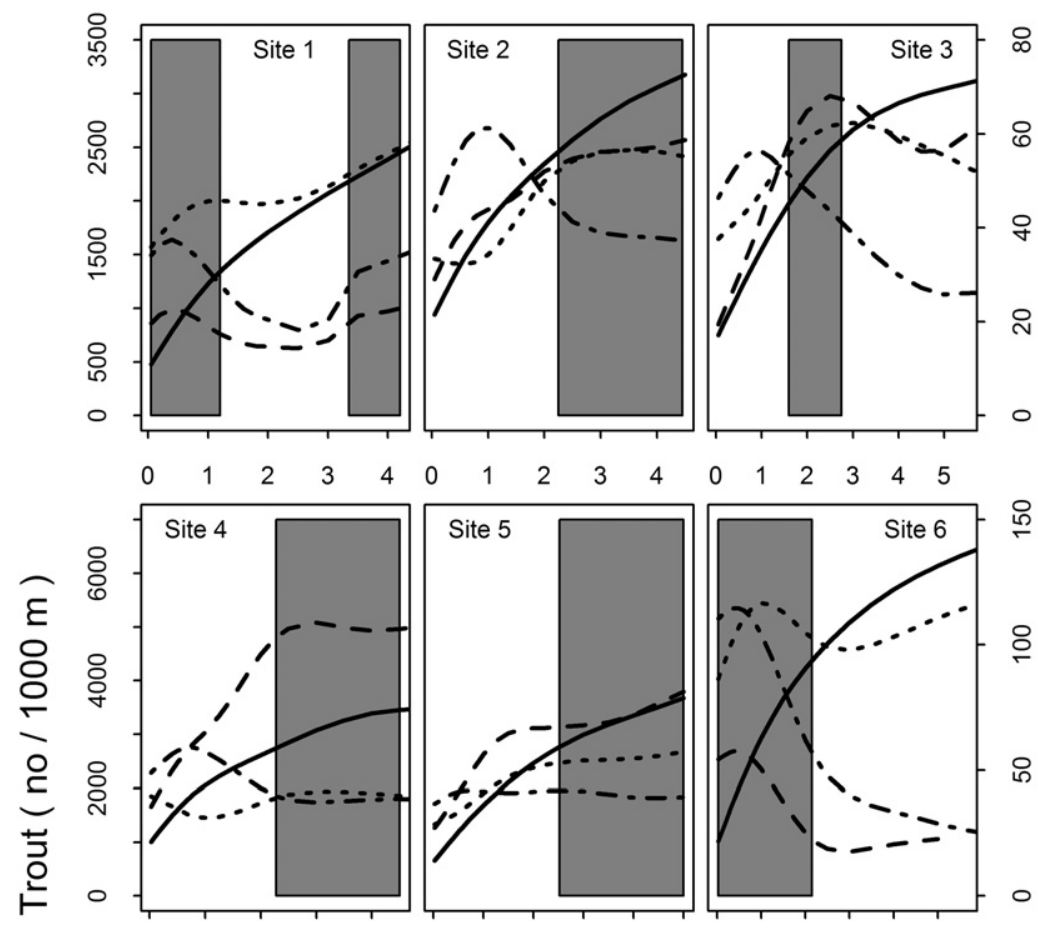

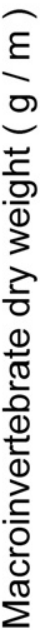
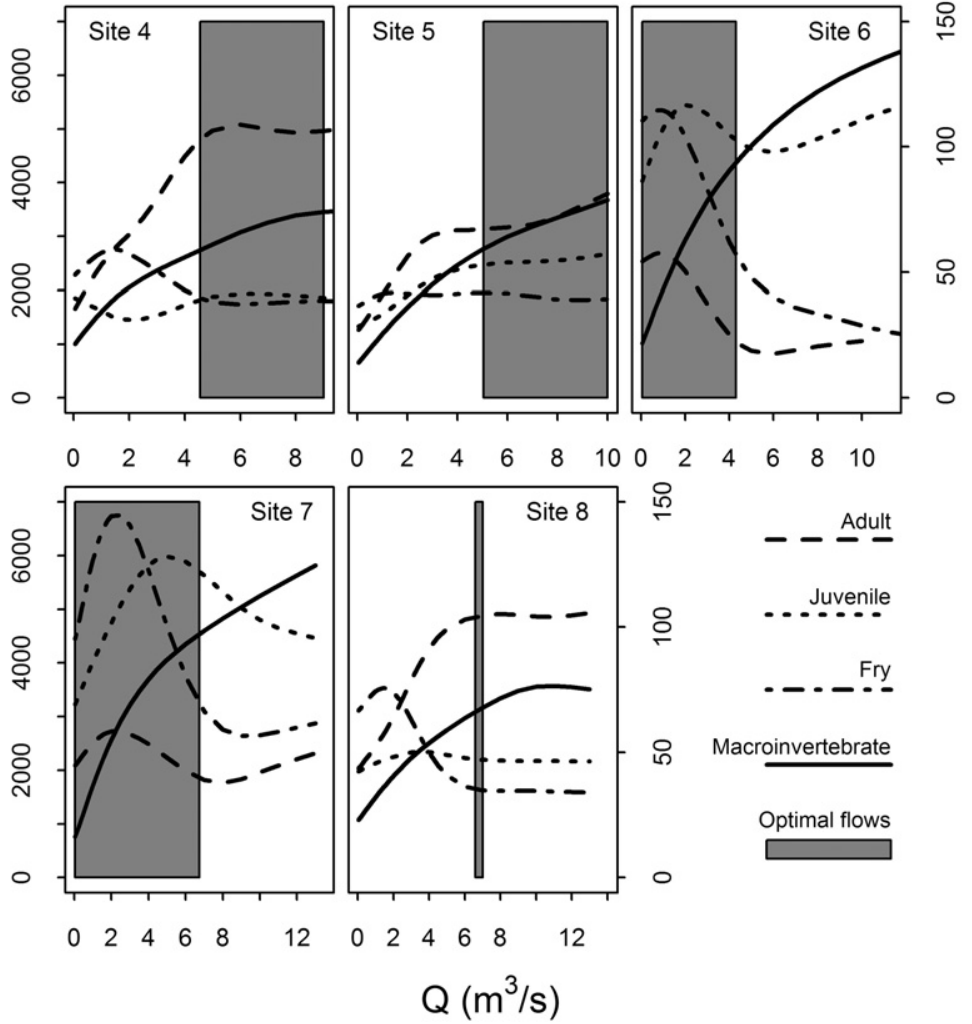

으 Macroinvertebrate

Optimal flows
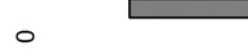

Fig. 5. Trends in available habitat for adult, juvenile, fry brown trout and potential macroinvertebrate biomass in the 8 modeled sites.

mesohabitat. The availability of refugia, evaluated as the fractions of available habitat that were characterized by discontinuity in the riverbed profile, where the depth of the water was over $0.30 \mathrm{~m}$ and the MSS was $>0.5 \mathrm{~m}$, had a significant effect only on adult trout densities. In fact, adult trout densities were greater in habitat with a greater proportion of refugia. Beside this habitat availability simulations shown

\section{Table 5}

Optimal flows calculated for the 8 modeled sites and relative biological metrics. Macroinvertebrate dry weight was compared to the worst situation inside the acceptable range of flows identified for fish.

\begin{tabular}{|c|c|c|c|c|c|}
\hline \multirow[b]{2}{*}{ Site } & \multirow[b]{2}{*}{$\mathrm{Q}_{\text {optimal }}\left(\mathrm{m}^{3} / \mathrm{s}\right)$} & \multicolumn{3}{|c|}{ Habitat availability (\%) } & \multirow{2}{*}{$\begin{array}{l}\text { Marcoinvertebrates Biomass } \\
\text { (\% increase) }\end{array}$} \\
\hline & & Adult & Juvenile & Fry & \\
\hline 1 & 1.200 & 77 & 80 & 74 & 180 \\
\hline 2 & 4.450 & 100 & 98 & 61 & 29 \\
\hline 3 & 2.750 & 100 & 100 & 73 & 30 \\
\hline 4 & 9.000 & 98 & 96 & 65 & 26 \\
\hline 5 & 10.000 & 100 & 100 & 94 & 33 \\
\hline 6 & 4.300 & 39 & 88 & 50 & 330 \\
\hline 7 & 6.750 & 68 & 95 & 48 & 499 \\
\hline 8 & 7.000 & 98 & 93 & 46 & 2 \\
\hline
\end{tabular}

different patterns in the different sites probably depending on the different mesohabitats gained or lost with increasing flows. This imply that the generalization of flow effect on habitat availability for adult trout is difficult because it strictly depends on the hydromorphological and hydraulic characteristics of each site.

On the other hand the density of juvenile brown trout were higher in habitats characterized by MSS between 0.4 and $0.7 \mathrm{~m}$, and as also for fry, shallow pools habitats could provide a better environment than others. Moreover the densities of brown trout fry increased in habitats with a great proportion of fine substrate. As a consequence, the habitat availability for young brown trout and fry decreases along with the decrease in shallow pool habitats in all the modeled sites. For flows over $50 \%$ of the mean annual discharge, most of the physical habitat for these life stages could be lost (Figs. 4 and 5).

\section{Conclusions}

Habitat models that predict flow-related changes in productivity are usually used for the definition of environmental flows, and thus the information they provide must be as accurate as possible and useful for the water managers. 
In our study we developed density-environment models for different life stages of brown trout at the mesohabitat scale. This improves in different ways the estimate of available habitat:

- the spatial scale of the data used for developing the biological models was the same used for making predictions;

- the different behaviors of the different life stages were taken into account and the optimal flows were defined on the basis of the needs of the different life stages;

- the changes in the available macroinvertebrate biomass were evaluated considering macroinvertebrates as the main food source for trout.

The trout number increased rapidly till a defined flow, under which the velocity remains quite low and the gained area is, at least in part, suitable. Above such threshold, mesohabitats switch from pools to riffles and runs that are less suitable for all the life stages.

Besides that, macroinvertebrates show a completely different pattern. In all the study sites the total density and biomass of the considered macroinvertebrate families always increased with increasing discharge. Modeling the habitat suitability of both trout life stages and their macroinvertebrate preys showed that habitats providing cover for feeding trout can be spatially separated from the habitats that provide the invertebrate food supply.

These findings should be taken in account as they have implications in flow management. On one hand, choosing an optimal flow that maximizes both habitat suitability for trout and invertebrate biomass at the same site, as we did in this work, allows to minimize the energetic trade-off that trout have to pay in order to forage when they leave their holding habitats. On the other hand, it is possible to consider a different spatial scale and to maximize only the holding conditions for trout in a given site, while most of the food production and, thus, the foraging can occur outside that site.

Looking at the limiting response of densities to flow-related variables seems a promising approach. This approach not only deals directly with density dataset, but involves also a different kind of interpretation of the relationships between available habitat and flow.

As physical habitat is a necessary, but not sufficient condition for the development and survival of fish, the results of habitat based models may best be viewed as indicators of population potential, in systems where the habitat conditions described by the models are the major population constraints. However, prey availability is always important for fish and our work shows clearly that taking into account the effect of flows management on macroinvertebrate population is fundamental in order to improve the assessment of optimal flows.

Supplementary data to this article can be found online at http://dx. doi.org/10.1016/j.scitotenv.2016.06.047.

\section{Acknowledgements}

We are grateful to Dijana Vracevic for the help in the fish sampling and to Brian S. Cade, Timo Muotka and two anonymous referees for their helpful comments on an earlier version of the manuscript.

\section{References}

Allen, D.C., Vaughn, C.C., 2010. Complex hydraulic and substrate variables limit freshwater mussel species richness and abundance. J. N. Am. Benthol. Soc. 29, 383-394.

Allouche, S., 2002. Nature and functions of cover for riverine fish. Bull. Fr. Peche Piscic 365/366, 297-324

AQEM Consortium, 2002. Manual for the application of the AQEM system. A Comprehensive Method to Assess European Streams Using Benthic Macroinvertebrates, Developed for the Purpose of the Water Framework Directive. Version 1.0

Armstrong, J.D., Kemp, P.S., Kennedy, G.J.J.A., Ladle, M., Milner, N.J., 2003. Habitat requirements of Atlantic salmon and brown trout in rivers and streams. Fish. Res. 62, $143-170$

Austin, M., 2007. Species distribution models and ecological theory: a critical assessment and some possible new approaches. Ecol. Model. 200, 1-19.
Ayllón, D., Almodóvar, A., Nicola, G.G., Elvira, B., 2009. Interactive effects of cover and hydraulics on brown trout habitat selection patterns. River Res. Appl. 25, 1051-1065.

Ayllón, D., Almodóvar, A., Nicola, G.G., Elvira, B., 2010. Modelling brown trout spatial requirements through physical habitat simulations. River Res. Appl. 26, 1090-1102.

Ayllón, D., Nicola, G.G., Parra, I., Elvira, B., Almodóvar, A., 2013. Intercohort density dependence drives brown trout habitat selection. Acta Oecol. 46, 1-9.

Bonada, N., Rieradevall, M., Dallas, H., Davis, J., Day, J., Figueroa, R., Resh, V.H., Prat, N., 2008. Multi-scale assessment of macroinvertebrate richness and composition in Mediterranean-climate rivers. Freshw. Biol. 53, 772-788.

Bridcut, P.S., Giller, E.E., 1995. Diet variability and foraging strategies in brown trout (Salmo trutta): an analysis from subpopulations to individuals. Can. J. Fish. Aquat. Sci. 52, 2543-2552

Bult, T., Riley, S., Haedrich, R., Gibson, R., Heggens, J., 1999. Density-dependent habitat selection by juvenile Atlantic salmon (Salmo salar) in experimental riverine habitats. Can. J. Fish. Aquat. Sci. 56, 1298-1306.

Burnham, K.P., Anderson, D.R., 2002. Model Selection and Multi-model Inference. second ed. Springer-Verlag, New York.

Cade, B.S., Noon, B.R., 2003. A gentle introduction to quantile regression for ecologists. Front. Ecol. Environ. 1, 412-420.

Cade, B.S., Terrell, J., Schroeder, R., 1999. Estimating effects of limiting factors with regression quantiles. Ecology 80, 311-323.

Canobbio, S., Mezzanotte, V., Ballabio, D., Pavan, M., 2008. Multi-criteria decision-making methods: a tool for assessing river ecosystem health using functional macroinvertebrate traits. In: Pavan, M., Todeschini, R. (Eds.), Data Handling in Science and Technology, Data Handling in Science and Technology. Elsevier, pp. 169-191.

Canobbio, S., Mezzanotte, V., Benvenuto, F., Siotto, M., 2010. Determination of Serio River (Lombardy, Italy) ecosystem dynamics using macroinvertebrate functional traits. Ital. J. Zool. 77, 227-240.

Comte, L., Buisson, L., Daufresne, M., Grenouillet, G., 2013. Climate-induced changes in the distribution of freshwater fish: observed and predicted trends. Freshw. Biol. 58, 625-639.

de Fraiture, C., Wichelns, D., 2010. Satisfying future water demands for agriculture. Agric. Water Manag. 97, 502-511.

Dolédec, S., Lamouroux, N., Fuchs, U., Mérigoux, S., 2007. Modelling the hydraulic preferences of benthic macroinvertebrates in small European streams. Freshw. Biol. 52, $145-164$

Doll, J.C., 2011. Predicting biological impairment from habitat assessments. Environ. Monit. Assess. 182, 259-277.

Downes, B.J., 2010. Back to the future: little-used tools and principles of scientific inference can help disentangle effects of multiple stressors on freshwater ecosystems. Freshw. Biol. 55, 60-79.

Eros, T., Gustafsson, P., Greenberg, L.a., Bergman, E., 2012. Forest-stream linkages: effects of terrestrial invertebrate input and light on diet and growth of brown trout (Salmo trutta) in a boreal forest stream. PLoS One 7

Fausch, K.D., 2014. A historical perspective on drift foraging models for stream salmonids. Environ. Biol. Fish 97, 453-464.

Fjeldstad, H.P., Barlaup, B.T., Stickler, M., Gabrielsen, S.E., Alfredsen, K., 2012. Removal of weirs and the influence on physical habitat for salmonids in a Norwegian river. River Res. Appl. 28, 753-763.

Fornaroli, R., Cabrini, R., Sartori, L., Marazzi, F., Vracevic, D., Mezzanotte, V., Annala, M., Canobbio, S., 2015. Predicting the constraint effect of environmental characteristics on macroinvertebrate density and diversity using quantile regression mixed model. Hydrobiologia 742, 153-167.

Gore, J.A., King, J., Hamman, K., 1991. Application of the instream flow incremental methodology to southern African rivers: protecting endemic fish of the Olifants River. Water SA 17, 225-236.

GRASS Development Team, 2012. Geographic resources analysis support system (GRASS) software, version 6.4.2. Open Source Geospatial Foundation. http://grass.osgeo.org.

Hansen, J., Hayes, D., 2012. Long-term implications of dam removal for macroinvertebrate communities in Michigan and Wisconsin rivers, United States. River Res. Appl. 28, $1540-1550$

Hesthagen, T., Heggenes, J., 2003. Competitive habitat displacement of brown trout by Siberian sculpin: the role of size and density. J. Fish Biol. 62, 222-236.

Johnson, J.B., Omland, K.S., 2004. Model selection in ecology and evolution. Trends Ecol. Evol. 19, 101-108.

Kail, J., Arle, J., Jähnig, S.C., 2012. Limiting factors and thresholds for macroinvertebrate assemblages in European rivers: empirical evidence from three datasets on water quality, catchment urbanization, and river restoration. Ecol. Indic. 18, 63-72.

Kaspersson, R., Sundström, F., Bohlin, T., Johnsson, J.I., 2013. Modes of competition: adding and removing brown trout in the wild to understand the mechanisms of density-dependence. PLoS One 8, e62517.

Koenker, R., 2015. Quantreg: quantile regression. R package version 5.19. http://CRAN.Rproject.org $/$ package $=$ quantreg

Koenker, R., Bassett, G., 1978. Regression quantiles. Econometrica 46, 33-50.

Lagarrigue, T., Céréghino, R., Lim, P., Reyes-Marchant, P., Chappaz, R., Lavandier, P., Belaud, A., 2002. Diel and seasonal variations in brown trout ( Salmo trutta) feeding patterns and relationship with invertebrate drift under natural and hydropeaking conditions in. Aquat. Living Resour. 15, 129-137.

Lancaster, J., Belyea, L., 2006. Defining the limits to local density: alternative views of abundance-environment relationships. Freshw. Biol. 51, 783-796.

Lecomte, J.-B., Laplanche, C., 2012. A length-based hierarchical model of brown trout (Salmo trutta fario) growth and production. Biometrical J. 54, 108-126.

Louhi, P., Mäki-Petäys, A., Huusko, A., Muotka, T., 2014. Resource use by juvenile brown trout and Alpine bullhead: influence of interspecific versus intraspecific competition. Ecol. Freshw. Fish 23, 234-243. 
Maddock, I., 1999. The importance of physical habitat assessment for evaluating river health. Freshw. Biol. 41, 373-391.

Mäki-Petäys, A., Muotka, T., Huusko, A., Tikkanen, P., Kreivi, P., 1997. Seasonal changes in habitat use and preference by juvenile brown trout, Salmo trutta, in a northern boreal river. Can. J. Fish. Aquat. Sci. 54, 520-530.

Menge, B.A., Gouhier, T.C., Freidenburg, T., Lubchenco, J., 2011. Linking long-term, largescale climatic and environmental variability to patterns of marine invertebrate recruitment: toward explaining "unexplained” variation. J. Exp. Mar. Biol. Ecol. 400, 236-249.

Moore, A., Bendall, B., Barry, J., Waring, C., Crooks, N., Crooks, L., 2012. River temperature and adult anadromous Atlantic salmon, Salmo salar, and brown trout, Salmo trutta. Fish. Manag. Ecol. 19, 518-526.

Morrissey, C.a., Boldt, A., Mapstone, A., Newton, J., Ormerod, S.J., 2013. Stable isotopes as indicators of wastewater effects on the macroinvertebrates of urban rivers. Hydrobiologia 700, 231-244.

Muñoz-Mas, R., Martínez-Capel, F., Schneider, M., Mouton, A.M., 2012. Assessment of brown trout habitat suitability in the Jucar River Basin (SPAIN): comparison of data-driven approaches with fuzzy-logic models and univariate suitability curves. Sci. Total Environ. 440, 123-131.

Muotka, T., Syrjänen, J., 2007. Changes in habitat structure, benthic invertebrate diversity, trout populations and ecosystem processes in restored forest streams: a boreal perspective. Freshw. Biol. 52, 724-737.

Neter, J., Wasserman, W., Kutner, M., 2004. Applied Linear Regression Models. fourth ed. McGraw- Hill/Irwin.

Nyström, P., Pérez, J.R., 1998. Crayfish predation on the common pond snail (Lymnaed stagnalis): the effect of habitat complexity and snail size on foraging efficiency. Hydrobiologia 368, 201-208.

O'brien, R.M., 2007. A caution regarding rules of thumb for variance inflation factors. Qual. Quant. 41, 673-690.

Parasiewicz, P., Walker, J.D., 2007. Comparison of MesoHABSIM with two microhabitat models (PHABSIM and HARPHA). River Res. Appl. 23, 904-923.

Poff, N., Allan, J., Palmer, M.A., Hart, D.D., Richter, B., Arthington, A.H., Rogers, K., Meyer, J. Stanford, J., 2003. River flows and water wars: emerging science for environmental decision making. Front. Ecol. Environ. 1, 298-306.
PTUA, 2006. Allegato 2. Progamma Di Tutela E Uso Delle Acque, Deliberazione N. 2244 del 29 Marzo 2006 Regione Lombardia, p. 28.

$\mathrm{R}$ Core Team, 2015. R: a language and environment for statistical computing. $\mathrm{R}$ found. Stat. Comput.

Rosenfeld, J., Ptolemy, R., 2012. Modelling available habitat versus available energy flux: do PHABSIM applications that neglect prey abundance underestimate optimal flows for juvenile salmonids? Can. J. Fish. Aquat. Sci. 69, 1920-1934.

Sánchez-Hernández, J., Cobo, F., 2012. Summer differences in behavioural feeding habits and use of feeding habitat among brown trout (Pisces) age classes in a temperate area. Ital. J. Zool. 79, 468-478.

Stoffels, R., Karbe, S., Paterson, R., 2003. Length-mass models for some common New Zealand littoral-benthic macroinvertebrates, with a note on within-taxon variability in parameter values among published models. N. Z. J. Mar. Freshw. Res. 37, 449-460.

Strakosh, T., Tr, S., Rm, N., Development, J.R.A., 2003. Development and assessment of habitat suitability criteria for adult brown trout in southern New England rivers. Ecol. Freshw. Fish 12, 265-274.

Towers, D.J., Henderson, I.M., Veltman, C.J., 1994. Predicting dry weight of New Zealand aquatic macroinvertebrates from linear dimensions. N. Z. J. Mar. Freshw. Res. 28, 159-166.

Van Liefferinge, C., Seeuws, P., Meire, P., Verheyen, R.F., 2005. Microhabitat use and preferences of the endangered Cottus gobio in the River Voer, Belgium. J. Fish Biol. 67 897-909.

Vismara, R., Azzellino, A., Bosi, R., Crosa, G., Gentili, G., 2001. Habitat suitability curves for brown trout (Salmo trutta fario L.) in the River Adda, Northern Italy: comparing univariate and multivariate approaches. Regul. Rivers Res. Manag. 50, 37-50.

Waddle, T., 2001. PHABSIM for Windows: User's Manual and Exercises. Open-File Report 01-340. US Geological Survey, Fort Collins, CO.

Winkle, W.V., Jager, H.I., Railsback, S.F., Holcomb, B.D., Studley, T.K., Baldrige, J.E., 1998. Individual-based model of sympatric populations of brown and rainbow trout for instream flow assessment : model description and calibration. Ecol. Model. 110, 175-207. 